\title{
Impacts of Short-term Sequential Stresses on Maize (Zea mays L.) and its Simulation using Info Crop-Maize Model
}

\author{
R.K. Fagodiya ${ }^{1 *}$, S. Naresh Kumar ${ }^{2}$ and R. Harit ${ }^{2}$ \\ ${ }^{1}$ ICAR-Central Soil Salinity Research Institute, Karnal, India \\ ${ }^{2}$ Centre for Environment Science and Climate Resilient Agriculture, \\ ICAR-Indian Agricultural Research Institute, New Delhi, India \\ *Corresponding author
}

\begin{tabular}{|c|c|}
\hline \multicolumn{2}{|r|}{ A B S T R A C T } \\
\hline & \multirow{6}{*}{$\begin{array}{l}\text { A field study was conducted with maize during monsoon season to quantify the response } \\
\text { of maize to short-term sequential stresses related to floods and drought. A simulation } \\
\text { analysis was also carried out using the InfoCrop maize model. The treatments of irrigated, } \\
\text { rainfed, drought and four different combinations of sequential stresses (rainfed, irrigation } \\
\text { and drought) at different phases of crop growth were imposed. Silking delayed by about } \\
\text { one week under adequate irrigation regime, as compared to that of rainfed crop, however } \\
\text { moderate drought advanced silking by } 10 \text { days. Grain yield was highest at the irrigated } \\
\text { condition. Imposition of sequential stresses RF-D-EW, D-RF-EW, EW-RF-D, D-EW-RF } \\
\text { and MD resulted in } 46.7 \%, 51.7 \%, 35 \%, 40 \% \text { and } 63.3 \% \text { decreased in grain yield } \\
\text { respectively over irrigated condition. The total biomass was decreased with RF-D-EW, D- } \\
\text { RF-EW, EW-RF-D, D-EW-RF and MD by } 34.7 \% \text {, 38.3\%, } 14.9 \%, 29.1 \% \text { and } 36.9 \% \\
\text { respectively. Maize model simulated days to } 50 \% \text { silking well in all situations of multiple } \\
\text { stresses except in case where rainfed crop was exposed to excess water/flooding during } \\
\text { flowering and then to terminal drought. The total dry matter and yield were also simulated } \\
\text { satisfactorily in most of the cases. The InfoCrop maize model worked satisfactorily for } \\
\text { rainfed and irrigated conditions and could be calibrated for the experiemental conditions. } \\
\text { However, refinement is needed from experimentation and model point of view for } \\
\text { simulating the multiple and sequential stress situations. }\end{array}$} \\
\hline Keywords & \\
\hline $\begin{array}{l}\text { Climatic variability, } \\
\text { Crop simulation } \\
\text { model, Phenology, } \\
\text { Growth, Yield. }\end{array}$ & \\
\hline Article Info & \\
\hline & \\
\hline & \\
\hline
\end{tabular}

\section{Introduction}

Maize (Zea mays L) is considered to be important from the point of view of its nutritional role and commercial value. It is referred as queen of cereals and it has the highest yield potential (Tollenaar and Lee, 2006). Maize is the third most important cereal crop and contributes 78.2 Mt to world total food grain production with an area about 150 Mha (McCann, 2007; Parihar et al., 2011). India is ranked sixth among maize producing countries with 9.4 Mha producing
$23.29 \mathrm{Mt}$ at a productivity of $2469 \mathrm{~kg} / \mathrm{ha}$ (FAO, 2013). In India, maize is the third most important food crops after rice and wheat. It is grown mainly during monsoon season which covers $80 \%$ area.

Climate change is projected to increase the frequency of heavy rainfall events and alter rainfall distribution, with former causing water logging conditions and the later resulting in dry spell or drought conditions. 
The flood and drought conditions may occur even in one season causing severe loss to the crop production. For instance, in India, in 2009, kharif season has experienced drought followed by flood situation in Andhra Pradesh, while in Bihar in 2010 kharif season first experienced flood followed by a long dry spell and then again flood situation. This caused immense loss to crop production. This situation implies that a crop may face multiple abiotic stresses in one season itself. More over the areas of cultivation of maize crop are either prone to drought or to floods. The impacts of drought and flood on crop growth and yield are multi-dimensional. Loss of turgidity, oxidative stress, loss of chlorophyll, hastening of leaf senescence, reduction in dry matter accumulation and poor seed set causes reduced yield in drought conditions (Prasad $e t$ al., 2008). Similarly, in poorly drained soils, low oxygen is a common environmental stress experienced by plants during flooding. Flooding affects the root activity and thus, in most crop plants, water logging causes severe injury affecting plant growth and yield (Liao and Lin, 2001). Flooding also causes the physiological drought and lodging of crop. Even though a considerable understanding is made on the impact of individual effect of drought and flood on maize crop, there is very less information available on how crops respond upon exposure to multiple stresses like droughts and floods or excess water situations occurring in sequence in their life cycle. In the climate change scenario, where increased variation in rainfall is projected, occurrence of dry spells and heavy rainfall events in a crop season may prove to be more detrimental for crop production. Therefore, it is important to study the impact of multiple stresses on crop so as to prepare the adaptation strategies (Fagodiya et al., 2011; 2017).

Simulating the crop growth and development using crop models has been increasingly become valuable for decision support, particularly in climatic risk conditions. Several crop models are being tested and validated for their performance for a given management, variety (ies) and climatic condition. However, their efficiency in simulating the crop response under sequential stresses is not tested enough. One of the reasons for such gap is availability of experimental data itself. In view of the importance of maize and projected increase in climatic variability exposing crop to multiple stresses even in single season at a given location, it is important to simulate the impacts using a crop model so as to improve the decision making on crop management and for developing the adaptation strategies at regional level. In this paper we first quantify the crop response to sequential stresses (excess water and dry spells in a single growing season) and then test the efficacy of an Info Crop-MAIZE model in simulating the crop response under such situations. Info Crop is a decision support system which can simulate the crop growth, development and yield in response to weather, soil, agronomic management (including planting, nitrogen, residues and irrigation), and major pests and diseases (Aggarwal et al., 2006).

\section{Materials and Methods}

\section{Experimental site and weather condition}

The field experiments was conducted during kharif season of 2010 in the Research Farm of Indian Agricultural Research Institute (latitude $28.4^{\circ} \mathrm{N}$ and longitude $77.11^{\circ} \mathrm{E}$ ), New Delhi. The soil has a pH of 8.16 and EC of $0.295 \mathrm{dS} \mathrm{m}^{-1}$ with a bulk density of 1.41 $\mathrm{Mg} / \mathrm{m}^{3}$. Soil texture is sandy loam with soil organic carbon of $0.28 \%$ and has the soil available N@170 kg ha ${ }^{-1}$, available P @ 8.88 $\mathrm{kg} \mathrm{ha}^{-1}$ and available K@207 kg ha ${ }^{-1}$. The field capacity of experimental field was $15.41 \% \mathrm{w} / \mathrm{w}$ and wilting point was $6.34 \%$ 
w/w. During the experimental period, monsoon rainfall was about $911 \mathrm{~mm}$. The daily mean sunshine duration was about 4.5 hrs. The mean value of evaporation was around $4.3 \mathrm{~mm} /$ day while the mean relative humidity (RH) was $78 \%$ during the south west monsoon. The mean maximum temperature was $32.5^{\circ} \mathrm{C}$ while the mean minimum temperature was $23.6^{\circ} \mathrm{C}$.

\section{Treatments}

Field experiment was laid out under homogenous condition of field with treatments of flooding and drought alone and in five different combinations at different phases of crop growth viz., Irrigated as and when required (I); Rainfed (RF); RainfedModerate drought-Excess water (RF-D-EW); Moderate drought-Rainfed-Excess water (DRF-EW); Excess water- Rainfed-Moderate drought (EW-R-D); Moderate drought-Excess water-Rainfed (D-EW-RF); Moderatedrought (MD). Each treatment was replicated three times. Overall, 7 treatments were replicated thrice. In order to attain the initial uniform stand, crop was maintained stress free till 15 DAS. Once crop attained a uniform stand (15 DAS), initial stress was given in each case and this was maintained for about one month (15-50 DAS). There after second stress (50-80 DAS) was given to crops for next 30 days and then the third stress (80100 DAS) was given, so as to ensure that crop was exposed to different stresses during its growth period in the sequence given earlier.

In case of excess water conditions, the plots were irrigated every morning till flooding was achieved. As the soil was highly porous, continuous standing water for days together could not be strictly achieved. However, the soil moisture was kept to saturation level (25 percent moisture level w/w) and therefore the treatment is designated as excess water treatment.

\section{Crop variety}

The maize hybrid HQPM-1 (a cross between HKI 193-1 × HKI 163), suitable for cultivation across the India is a late duration variety with yellow color dent type seed with average yield of about $60 \mathrm{q} / \mathrm{ha}$. This hybrid is resistant to frost/cold and also to common rust.

\section{Sowing of crop and its management}

The seeds of maize hybrid HQPM-1 were dibbled along the rows spaced at $60 \mathrm{~cm}$ apart with plant to plant spacing of $20 \mathrm{~cm}$ at a depth of $5 \mathrm{~cm}$, using $20 \mathrm{~kg}$ seeds/ha. Sowing was done on 10 July, 2010. All plots received phosphorus@60 $\mathrm{P}_{2} \mathrm{O}_{5} \mathrm{~kg} \mathrm{ha}^{-1}$ through SSP, potassium@60 kg ha ${ }^{-1}$ through MOP at the time of sowing. Nitrogen@120 $\mathrm{kg} \mathrm{ha}^{-1}$ was applied in the form of urea in three equal split doses viz., 1/3 as basal, 1/3 at knee high stage and $1 / 3$ at tasseling stage. Atrazine at $1.0 \mathrm{~kg}$ $\mathrm{ha}^{-1}$ was applied two days after sowing as preemergence to control the initial flushes of weeds. In addition to this two time manual weeding was done at 45 DAS and 85 DAS. Soil moisture in different treatments at the beginning of each stress was estimated using gravimetric method. The moisture status of soil varied from $8.36 \%$ to $25.43 \%$ in various treatments at different crop growth stages. Prior to the first stress, soil moisture was $13.72 \%$ and varied significantly during the course of crop growth due to variation in treatments.

\section{Sampling and observations}

Observations on phenology (Days to $50 \%$ germination, $50 \%$ silking and $50 \%$ physiological maturity) were taken on plants in different treatments. Observations on yield and yield components were also taken at the harvest. Mature cobs and stover were harvested manually from one square meter 
area and sun dried for few days. Then the dried cobs were dehusked and shelled manually and grain yield was recorded at $15 \%$ moisture content and expressed in $\mathrm{kg} \mathrm{ha}^{-1}$. The number of rows and number of grains or kernels per cob were counted from five randomly selected cobs in each plot. Shelling percentage $(\%)$ and harvest index (HI) were calculated using:

$$
\begin{aligned}
& \text { Shelling percentage }(\%)=\frac{\text { Grain weight }\left(\mathrm{kgha}^{-1}\right)}{\text { Cob weight }\left(\mathrm{kgha}^{-1}\right)} \times 100 \\
& \text { Harvest index }=\frac{\text { Grain yield }\left(\mathrm{kgha}^{-1}\right)}{\text { Grain+stover yield }\left(\mathrm{kgha}^{-1}\right)} \times 100
\end{aligned}
$$

\section{Statistical analysis}

The data on phenology, yield variables and grain yield of maize were analyzed by applying the technique of 'analysis of variance (ANOVA)' for Randomized Block Design using SPSS 16.0 software. Critical difference (CD) was calculated at 5\% level of significance for comparing the treatment means. $C D$ values have been indicated, where the differences are significant.

\section{Calibration and validation of info crop- maize model}

In order to test the model performance in simulating the response of crop to multiple stresses, Info crop model was used. The simulated values on phenology (days to $50 \%$ flowering, grain filling duration), total dry matter (TDM) and grain yield (GY) were compared with those of observed values. The observed data set on both irrigated and rainfed plants from the field experiment were used for the calibration and fine tuning of the model.

Initially, the model was calibrated for varietal performance using the varietal characteristics for irrigated conditions. For attaining the proper phenology, total dry matter and yield, several iterations were done and simulations runs were made. After satisfactory performance of model in irrigated conditions, the simulations were done for rainfed conditions and calibration was repeated through less iteration so as to get proper simulation results in rainfed conditions as well. To simulate the multiple stresses, conditions were imposed and tested the model performance. The calibrated model then was used to simulate the response of maize crop to multiple stresses in a crop growth period. The remainig five treatments viz. MD; RF-D-EW; D-RF-EW; EW-RF-D and D-EW-RF in maize crop was used for the simulation purpose.

\section{Evaluation of model performance}

Three statistical measures and indices were applied to evaluate the model that included mean bias error (MBE) (Addiscott and Whitmore 1987), root mean square error (RMSE) (Fox 1981) and modeling efficiency (ME) (Nash and Sutcliffe 1970).

$$
\boldsymbol{M B E}=\frac{1}{n} \sum_{i=1}^{n}(S i-O i)
$$

$$
\begin{gathered}
\text { RMSE }=\sqrt{\frac{1}{n} \sum_{i=1}^{n}(S i-O i)^{2}} \\
M E=1-\frac{\sum_{i=1}^{n}\left(S_{i}-O_{i}\right)^{2}}{\sum_{i=1}^{n}\left(\left|O_{i}-\bar{O}\right|\right)^{2}}
\end{gathered}
$$

Where $\mathrm{n}$ is the number of samples, $\mathrm{Si}$ and $\mathrm{Oi}$ are the simulated and observed values respectively, and $\overline{\mathrm{O}}$ is the mean of the observed data. The MBE indicates bias of model error as it accounts for positive and negative deviations. The RMSE describes 
mean absolute deviation between simulated and observed values. Accuracy of simulation is characterized by lower RMSE. ME allows negative values and compares deviation between simulated and observed state variables with the variances of observed values of development, growth and yield.

\section{Results and Discussion}

\section{Crop phenology}

The days to $50 \%$ germination not affected significantly as the initial condition up to 15 DAS was similar in all the treatments. While, days to $50 \%$ silking and $50 \%$ physiological maturity was affected significantly due to effect of moisture related sequential stresses with the highest value observed at irrigation condition viz. 63 and 107 respectively (Table 1). Lowest values of $50 \%$ silking and $50 \%$ physiological maturity were recorded at moderate drought condition.

Under adequate irrigation regime, silking delayed by about one week as compared to that of rainfed crop, while the moderate drought advanced silking by 10 days as compared to that of adequately irrigated crop (Table 1). Coincidence of vegetative period with moderate drought advanced silking while with excess water it delayed.

\section{Yield parameters}

The yield attributes of maize such as number of rows per cob, number of grains per cob, shelling percentage (Table 2) and harvest index (Table 3) differed significantly (CD $\mathrm{p}=0.05)$ due to sequential stresses related to flood and draught with the highest values observed at irrigated condition and lowest values under moderate draught condition. Numbers of grain rows were same under RF and EW-RF-D, while it was also same in RFD-EW and D-RF-EW treatments. Excess water during grain filling period also led to reduced number of grains per cob. The highest value of the shelling percentage was recorded under irrigated condition followed by the EW-RF-D, while the lowest value was recorded under the moderate drought condition. Same value of shelling percentage was recorded under RF and RF-D-EW treatments. Same value of harvest index was recorded in D-RF-EW and EW-RF-D treatments (Table 3). There was no significant effect of these stresses on 100 grain weight (Table 2).

\section{Grain yield and total biomass yield}

The grain yield, cob weight and total biomass were significantly affected by multiple stresses related to climate change (Table 3 ). The grain yield was highest in the irrigated condition, while lowest value was recorded under the moderate condition. Grain yield was almost similar in rainfed grown crop or in crop subjected to EW-RF-D conditions. Occurrence of drought during vegetative growth period or during flowering caused more reduction in grain yield. With imposition of stresses RF-D-EW, D-RF-EW, EW-RF-D, D-EW-RF and MD resulted in $46.7 \%, 51.7 \%, 35 \%, 40 \%$ and $63.3 \%$ decreased in grain yield respectively over irrigated condition. Highest value of total biomass was recorded under the irrigated condition, while the lowest value was recorded in the (D-RF-EW) which was at par with MD (Table 3). The total biomass was decreased with RF-D-EW, D-RF-EW, EWRF-D, D-EW-RF and MD by 34.7\%, 38.3\%, $14.9 \%, 29.1 \%$ and $36.9 \%$ respectively.

\section{Calibration of info crop-maize model}

The model parameters and interpolation functions were calibrated for maize hybrid (HQPM-1) from the field experiment data set. 
Table.1 Effect of moisture related sequential stresses on phenology and leaf area index of maize crop in monsoon season

\begin{tabular}{llccc}
\hline \multirow{2}{*}{$\begin{array}{l}\text { Initial condition } \\
\text { (up to 15 DAS) }\end{array}$} & Treatment & $50 \%$ Germination & $50 \%$ Silking & $\begin{array}{c}\text { 50\% Physiological } \\
\text { maturity }\end{array}$ \\
\cline { 3 - 5 } & & 6 & 63 & 107 \\
RF & I & 7 & 56 & 97 \\
RF & RF & 6 & 58 & 101 \\
RF & RF-D-EW & 6 & 54 & 102 \\
RF & D-RF-EW & 6 & 65 & 105 \\
RF & EW-RF-D & 7 & 58 & 101 \\
RF & D-EW-RF & 6 & 53 & 94 \\
RF & MD & NS & 1.44 & 1.72 \\
\multicolumn{1}{l}{ I=Irrigated as and when required; RF=Rainfed; RF-D-EW=Rainfed-moderate drought-excess water; D-RF- } \\
EW=Moderate drought-rainfed-excess water; EW-RF-D=Excess & water-rainfed- moderate drought; D-EW- \\
RF=moderate drought-excess water-rainfed; MD=Moderate-drought &
\end{tabular}

Table.2 Effect of moisture related sequential stresses on yield components of maize crop

\begin{tabular}{llcccc}
\hline $\begin{array}{l}\text { Initial condition (up } \\
\text { to 15 DAS) }\end{array}$ & Treatment & $\begin{array}{c}\text { Rows cob }^{-1} \\
(\mathrm{No})\end{array}$ & $\begin{array}{c}\text { Grain cob }^{-1} \\
(\mathrm{No})\end{array}$ & $\begin{array}{c}100 \text { grain } \\
\text { weight }(\mathrm{g})\end{array}$ & $\begin{array}{c}\text { Shelling } \\
\%\end{array}$ \\
\hline RF & I & 13 & 285 & 26.7 & 77 \\
RF & RF & 12 & 221 & 25.3 & 72 \\
RF & RF-D-EW & 11 & 158 & 24.8 & 72 \\
RF & D-RF-EW & 11 & 171 & 25.5 & 73 \\
RF & EW-RF-D & 12 & 219 & 25.8 & 76 \\
RF & D-EW-RF & 10 & 155 & 25.1 & 74 \\
RF & MD & 9 & 92 & 24.1 & 66 \\
& CD p=0.05 & 1.65 & 53.18 & NS & 3.62 \\
\hline
\end{tabular}

*For treatment details refer the foot note of table 1

Table.3 Effect of moisture related sequential stresses on grain yield, cob weight and total biomass yield $\left(\mathrm{kg} \mathrm{ha}^{-1}\right)$ of maize crop

\begin{tabular}{llcccc}
\hline $\begin{array}{l}\text { Initial condition (up } \\
\text { to 15 DAS) }\end{array}$ & Treatment & $\begin{array}{c}\text { Grain } \\
\text { yield }\end{array}$ & $\begin{array}{c}\text { Cob } \\
\text { weight }\end{array}$ & $\begin{array}{c}\text { Total } \\
\text { biomass }\end{array}$ & $\begin{array}{c}\text { Harvest } \\
\text { index }\end{array}$ \\
\hline RF & I & 5000 & 6493 & 11750 & 43 \\
RF & RF & 3250 & 4530 & 9583 & 34 \\
RF & RF-D-EW & 2667 & 3726 & 7667 & 35 \\
RF & D-RF-EW & 2417 & 3325 & 7250 & 33 \\
RF & EW-RF-D & 3250 & 4271 & 10000 & 33 \\
RF & D-EW-RF & 3000 & 4032 & 8333 & 36 \\
RF & MD & 1833 & 2797 & 7417 & 25 \\
\hline & CD p=0.05 & 375 & 446 & 627 & 6.22 \\
\hline
\end{tabular}

*For treatment details refer the foot note of table 1 
Table.4 Observed and simulated value of the calibration of Info Crop-Maize model

\begin{tabular}{lrrrr}
\hline \multirow{2}{*}{ Parameters } & \multicolumn{2}{c}{ Irrigated } & \multicolumn{2}{c}{ Rainfed } \\
\cline { 2 - 5 } & Observed & Simulated & Observed & Simulated \\
\hline Days to 50\% silking (from DAS) & 63 & 62 & 56 & 56 \\
Grain filling duration (days) & 44 & 45 & 41 & 44 \\
Total dry matter (kg. ha ${ }^{-1}$ ) & 11750 & 12872 & 9583 & 10551 \\
Grain yield (kg. ha ha $^{-1}$ ) & 5000 & 5161 & 3250 & 3831 \\
\hline
\end{tabular}

Table.5 Statistical indices showed performance of Info Crop-Maize model

\begin{tabular}{lrrr}
\hline Parameters & MBE & RMSE & ME \\
\hline Days to 50\% silking (from DAS) & -4.80 & 7.92 & -2.52 \\
Grain filling duration (days) & -2.40 & 7.59 & -6.58 \\
Total dry matter $\left(\mathrm{kg} . ~^{-1}\right)$ & -1122.00 & 1985.00 & -2.91 \\
Grain yield $\left(\mathrm{kg}^{-1} \mathrm{ha}^{-1}\right)$ & -2.20 & 769.00 & -1.46 \\
\hline
\end{tabular}

$\mathrm{MBE}=$ Mean bias error; RMSE=Root mean square error; ME=Modeling efficiency

Fig.1 Validation results on Info Crop-Maize model for simulating the effect of multiple-stresses on ground nut crop on A) days to $50 \%$ silking from DAS, B) grain filling duration in days, C) total dry matter $\left(\mathrm{kg} . \mathrm{ha}^{-1}\right)$ and D) grain yield $\left(\mathrm{kg} . \mathrm{ha}^{-1}\right)$
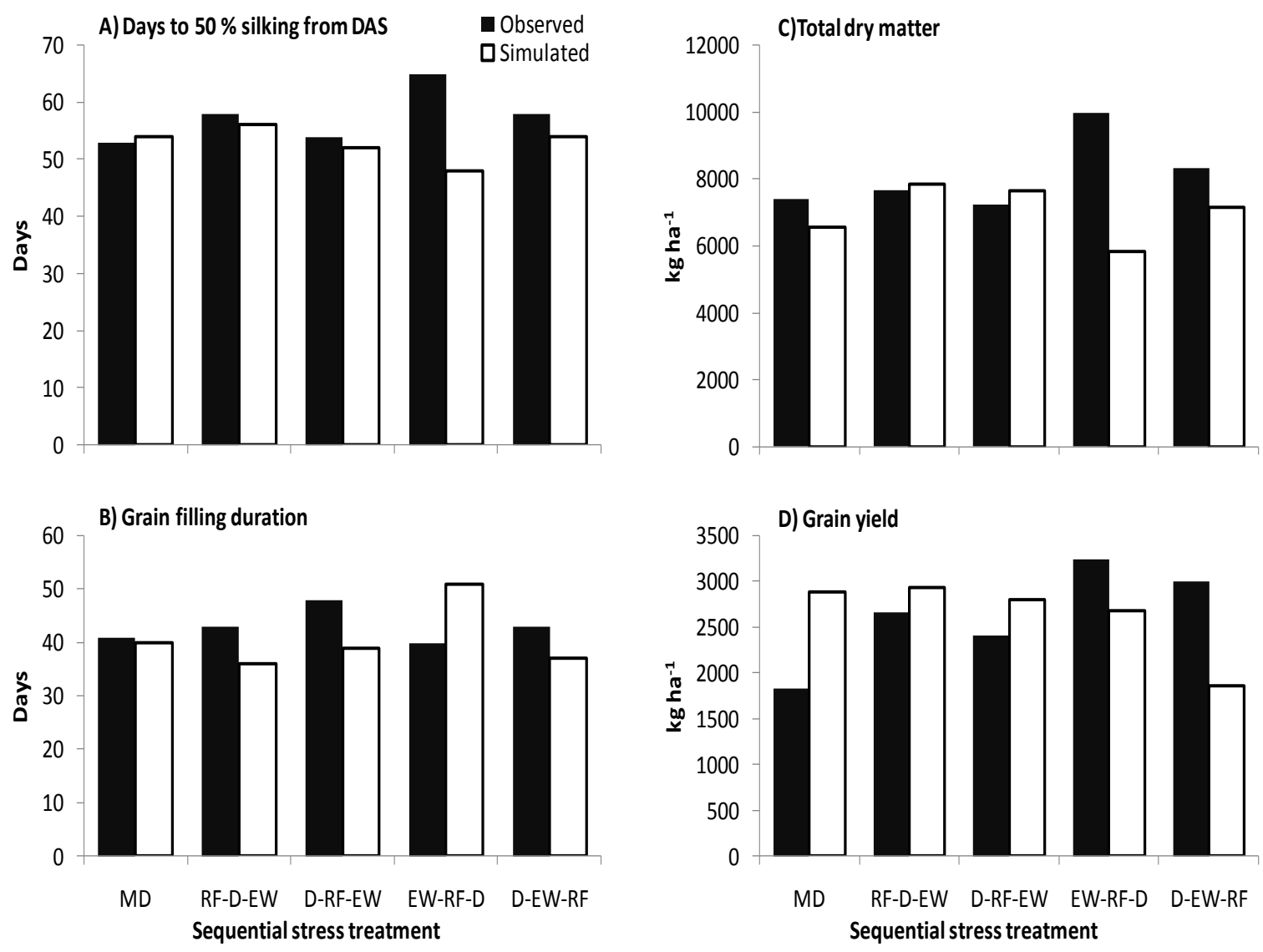
The simulated phenology (days to $50 \%$ silking and grain filling duration) almost matched with that of observed values under the irrigated condition, while the observed and simulated values on grain filling duration was 41 and 44 days respectively and simulated value was slightly higher than the observed one (Table 4). The simulated values of total dry matter and grain yield under irrigated condition and total matter under rainfed condition matched with those of observed ones. Under rainfed condition the simulated and observed values on grain yield was 3250 and $3831 \mathrm{~kg} \mathrm{ha}^{-1}$ respectively. All these above parameters showed satisfactory performance of model when compare with the observed values and the deviation was within the acceptable limits of $10 \%$.

\section{Simulating the crop response to multiple stresses}

Comparision between observed and simulated values showed that days to $50 \%$ silking was simulated well by the model except in EWRF-D treatment where the simulated value was much lower than the observed value (Fig. 1A). Results showed that the grain filling duration was simulated well only in moderate draught (MD) treatment (Fig. 1B). The simulated value for grain filling duration was 11 days lower than the observed value in DRF-EW treatment and 11 days higher than the observed value in EW-RF-D treatment. In EW-RF-D condition the simulated value for grain filling durationwas much higher than the observed one. Total dry matter was simulated well in RF-D-EW and D-RF-EW conditions (Fig. 1C) where simulated values for total dry matter was 2.4 and $5.4 \%$ higher than the observed one. In MD and D-EW-RF conditions the simulated value for total dry matter was lower than the observed one and it was lower by 13.3 and $16.2 \%$ respectively. It was found that in EW-RF-D condition the simulated value for total dry matter is about half than the observed one.Grain yield was simulated well in treatments RF-D-EW and D-RF-EW only (Fig. 1D) where simulated value was higher by 8.9 and $13.7 \%$ respectively. The grain yield was over estimated in moderate draught (MD) condition and the simulated value of the grain yield was $36.6 \%$ higher than the observed. Under EW-RF-D and D-EW-RF conditions grain yield was under estimated and the simulated values for grain yield was 21.4 and $61.3 \%$ lower than the observed values respectively.

\section{Statistical performance of model}

From the data set it was observed that mean bias error (MBE) showed the negative deviation for the days to $50 \%$ silking, grain filling duration, total dry matter and grain yield (Table 5). Root mean square error (RMSE) values showed that the accuracy of model was higher for the days to $50 \%$ silking and grain filling duration, and it was lower for grain yield and total dry matter. Modeling efficiency also showed that under estimation of model for the crop parameters.

Overall results on phenology, biomass accumulation and distribution, yield and yield components indicate that the maize plants responded differentially to sequential stresses depending on the coincidence of the occurrence of type of stress. The sensitivity of crops and crop parameters also differed with regards to sequential stresses. The variation among crop species for response to droughts or floods is well documented (Liao and Lin, 2001; Prasad et al., 2008). In maize, drought stress caused reduction in vegetative phase, grain filling period and therefore crop growth period. Excess water during grain filling period delayed the crop maturity. The total biomass was most affected in plants exposed to drought stress during the vegetative growth period and then subjected to excess water 
during grain filling period. Continuous drought condition caused most reduction in total biomass. Maize has been reported to be very sensitive to drought (Farre et al., 2000) as it leads to reduction in growth, content of chlorophyll pigments (Lima et al., 2002), nutrient uptake, impaired active transport (Tanguilig et al., 1987). Flooding/water logging leading to anaoxia causing severe injury and yield loss (Voesenek et al., 2006).Flooding also causes reduction in photosynthetic capacity, root injury, reduced water uptake, (Jackson, 2002 and Yordanova et al., 2005), reduction in fresh and dry weight (Seema et al., 2009) and reduction in leaf number (Ali et al., 1999).

The yield and yield parameters were also influenced by the sequential stresses. Moderate drought condition reduced the cob weight, number of grain rows, number of grain per cob, harvest index and shelling percentage. Excess water during grain filling period also led to reduced number of grains per cob. The grain yield was significantly highest in the irrigated condition, while the lowest value was recorded under the moderate drought condition. Grain yield was almost similar in rainfed grown crop or in crop subjected to EW-RF-D conditions. Occurrence of drought during vegetative growth period or during flowering caused more reduction in grain yield. Even though 100 grain weight was not affected significantly by the occurrence of different stresses, maximum weight of 100 grains was recorded in irrigated condition while the least weight was recorded in moderate drought condition. Same value of harvest index was recorded in D-RF-EW and EW-RF-D treatments and similar values of shelling percentage were recorded under RF and RF-D-EW treatments. Stress just before anthesis and at anthesis caused significant increase in floral abortion and lower seed numbers in maize (Claassen and Shaw, 1970). Post-anthesis moisture deficit on the other hand significantly reduced grain yield (Olaoye et al., 2009). Flooding and submergence caused by heavy rainfall, water logging in poorly drained soil or high water table is one of the most common constraints for maize production
(Zaidi et al., 2005). In maize early seedling stage was found to be highly susceptible, followed by the knee-high stage (Zaidi and Singh 2002; Zaidi et al., 2004) to flooding or excess moisture.

The simulation analysis indicated that the InfoCrop model on maize worked satisfactorlly for rainfed and irrigated conditions and could be calibrated for the experiemental conditions for these treatments. Maize model simulated days to $50 \%$ silking well in all sitiations of multiple stresses except in case where rainfed crop was exposed to excess water/flooding during flowering and then to terminal drought. Grain filling duration was also simulated well in moderate drought conditions but in other sitiations it slightly under-estimated the duration except where crop was exposed to terminal drought. As a consequence, the total dry matter and yield also was simulated satisfactorily in most of the cases. The temperature and rainfall intercational influnces were satisfactrily simuated using InfoCrop maize (Byjeah et al., 2010) and sorghum (Srivastava et al., 2010) models. However, there is a need for more refinement from the experimentaion and model point of view for carrying out better simulations of situations where maize is exposed to excess water/flooding in vegetative period and then to terminal droughts as also in case of occurance of droughts duing vegetative period and then exposed to excess water/flooding coinciding with flowering and initial grainfilling period.

The results indicated that the impacts of drought and flood on crop growth and yield are multidimensional. The sensitivity of crops and crop parameters also differed with regards to sequential stresses. The drought condition hastened the occurrence of crop phenological events in maize and coincidence of drought situation with early growth period hastened flowering, while excess water caused delay in flowering and crop maturity. The total biomass was most affected in plants exposed to drought stress during the vegetative growth period and then subjected to excess water during grain 
filling period. Occurrence of drought during vegetative growth period or during flowering caused more reduction in grain yield. The simulation analysis indicated the Info Crop maize model could be satisfactorily calibrated to rainfed and irrigated conditions. The maize model was robust in simulating the effects of sequential multiple stresses except in few events such as when maize is exposed to excess water/flooding in vegetative period and then to terminal droughts as also in case where crop exposed to droughts during vegetative period and then to excess water/flooding coinciding with flowering and initial grainfilling period. Results also indicate that, more experimentation is required to test the performance of models in these situations and also for refining them.

\section{Acknowledgements}

We are grateful to the Centre for Environment Science and Climate Resilient Agriculture, Indian Agricultural Research Institute, New Delhi for necessary services and help provided during the research work and Indian council of agriculture research, New Delhi for Junior Research Fellowship.

\section{References}

Addiscott, T.M. and Whittmore, A.P. 1987. Computer simulation of changes in soil mineral nitrogen during autumn, winter and spring. The Journal of Agricultural Science. 109: 141-157.

Aggarwal, P. K., Kalra, N., Chander, S. and Pathak, H. 2006. InfoCrop: A dynamic simulation model for the assessment of crop yields, losses due to pests, and environmental impact of agro-ecosystems in tropical environments. I. Model description. Agricultural Systems. 89: 125.

Ali, M. A., Golam, A. K. M. and Azad, A. K. M. 1999. Effect of water stresses on the growth features of different maize (Zea Mays L.) cutlivars. Pakistan Journal of Botany. 31 (2): 455-460.

Byjesh, K., Naresh Kumar, S. and Aggarwal, P.
K. 2010. Simulating impacts, potential adaptation and vulnerability of maize to climate change in India. Mitigation Adaptation Strategies for Global Change. 15: 413-431.

Claassen, M. M. and Shaw, R. H. 1970. Water deficit effects on corn. II. Grain components. Agronomy Journal. 62: 652655.

Fagodiya, R.K. 2011. Impact of climate related multiple stresses on maize and groundnut. ICAR-Indian Agricultural Research Institute, New Delhi. MSc Thesis. DOI:10.13140/RG.2.2.21456.61443.

Fagodiya, R.K., Pathak, H., Bhatia, A., Kumar, A., Singh, S.D., Jain, N. and Harith., R. 2017. Simulation of Maize (Zea mays L.) Yield Under Alternative Nitrogen Fertilization Using Infocrop-Maize Model. Biochem. Cell. Arch. 17(1): 6571.

FAO, 2013. Food and Agriculture Organization of the United Nation, Rome, Italy. available online at http://faostat3.fao.org/download/Q/QC/E; Accessed on 20/02/2016

Farre, I., Van Oijen, M., Leffelaar, P. A. and Faci J, M. 2000. Analysis of maize growth for different irrigation strategies in northeastern Spain. European journal of agronomy 12 (3): 225-238.

Fox, D. G. 1981. Judging air quality model performance: a summary of the AMS Workshop on dipression model performance. Bulletin of the American Meteorological Society. 62: 599-609.

Jackson, M. 2002. Long-distance signalling from roots to shoots assessed: the flooding story. Journal of Experimental Botany. 53: 175-181.

Liao, C. T. and Lin, C. H. 2001. Physiological adaptation of crop plants to flooding stress. Proceedings of the National Science Council, Republic of China. Part B, Life Sciences. 25 (3): 148-157.

Lima, A. L. S., Da Matta, F. M., Pinheiro, H. A., Totola, M. R., Loureiro, M. E., 2002. Photochemical responses and oxidative stress in two clones of Coffeacanephora 
under water deficit conditions. Environmental and Experimental Botany. 47: 239-247.

McCann, J. C. 2007. Maize and Grace: Africa's Encounter with a New World Crop, 15002000, Harvard University Press, Cambridge.

Nash, J. E. and Sutcliffe, I. V. 1970. River flow forecasting through conceptual model. Journal of Hydrology. 273: 282-290.

Olaoye, G., Bello, O. B., Abubakar, A. Y. Olayiwola, L. S. and Adesina, O. A. 2009. Analyses of moisture deficit grain yield loss in drought tolerant maize (Zea mays L.) germplasm accessions and its relationship with field performance. African Journal of Biotechnology. 8 (14): 3229-3238

Parihar, C. M., Jat, S. L., Singh, A. K., Hooda, K. S., Chikkappa G. K., Singh, D. K. and Saikumar, R. 2011. Maize Production Technologies. Technical Bulletin 2011/3, pp.36. Directorate of Maize Research, New Delhi.

Prasad, P. V. V., Pisipati, S. R., Mutava, R. N. and Tuinstra, M. R. 2008. Sensitivity of sorghum to high temperature stress during reproductive development. Crop Science. 48: 1911-1948.

Seema, B., Harpreet, K. and Gurjit, K. G. 2009. Effect of flooding stress on seedling growth and protein profile of roots in maize. Indian Journal of Plant Physiology 14 (2): 135-141.

Srivastava, A., Naresh Kumar, S. and Aggarwal, P. K. 2010. Assessment on vulnerability of sorghum to climate change in India. Agriculture, Ecosystems \& Environment. 138: 160-169.
Tanguilig, V. C., Yambao, E. B., O'Toole, J. C. and De Datta, S. K. 1987. Water stress effects on leaf elongation, leaf water potential, transpiration, and nutrient uptake of rice, maize, and soybean. Plant and Soil. 103: 155-168.

Tollenaar, M. and Lee, E. A. 2006. Dissection of physiological processes underlying grain yield in maize by examining genetic improvement and heterosis. Maydica. 51: 399-408.

Voesenek, L. J., Colmer, C. D., Pierik, R., Millenaar, F. F. and Peeters. A. J. M. 2006. How plants cope with complete submergence. New Phytologist. 170: 213 226.

Yordanova, R., Uzunova, A. and Popova, L. 2005. Effects of short-term soil flooding on stomata behaviour and leaf gas exchange in barley plants. Biologia Plantarum. 49: 317-319.

Zaidi, P. H. and Singh, N. N. 2002. Identification of morph physiological traits for excess soil moisture tolerance in maize In: Bora KK, Singh K, Kumar A, eds, pp. 172-183. Scientific Publishers, Jodhpur, India.

Zaidi, P. H., Rafique, S., Rai, P. K., Singh, N. N. and Srinivasan, G. 2004. Tolerance to excess moisture in maize (Zea mays L.): susceptible crop stages and identification of tolerant genotypes. Field Crops Research. 90: 189-202.

Zaidi, P. H., Selvan, P. M., Sultana, R., Yadav, P., Singh, R. P., Singh, N. N. and Srinivasan, G. 2005. In: Zaidi, P. H. and Singh, N. N. eds, Stresses on Maize in Tropics. pp. 100-34. Directorate of Maize Research, Pusa Campus, New Delhi.

\section{How to cite this article:}

Fagodiya, R.K., S. Naresh Kumar and Harit, R. 2017. Impacts of Short-term Sequential Stresses on Maize (Zea mays L.) and its Simulation using Info Crop-Maize Model. Int.J.Curr.Microbiol.App.Sci. 6(12): 911-921. doi: https://doi.org/10.20546/ijcmas.2017.612.099 